\title{
Morphometry and Morphology of the Acetabulum Within the Black African Population of South Africa
}

\author{
Morfometría y Morfología del Acetábulo Dentro de la Población Africana Negra de Sudáfrica
}

K. Indurjeeth ${ }^{1}$; S Ishwarkumar1; BZ De Gama ${ }^{1}$; Z Ndlazi1 \& P Pillay ${ }^{1}$

\begin{abstract}
INDURJEETH, K.; ISHWARKUMAR, S.; DE GAMA, B. Z.; NDLAZI, Z. \& PILLAY, P. Morphometry and morphology of the acetabulum within the black African population of South Africa. Int. J. Morphol., 37(3):971-976, 2019.

SUMMARY: The acetabulum is the large cup-shaped cavity on the lateral surface of the hip bone, which articulates with the head of the femur to form the hip joint. The morphometry and morphology of the acetabulum is important in the diagnosis and treatment of hip joint injuries and disease. Population specific differences exist regarding the acetabulum, therefore, this study aimed to document the morphometry and morphology of the acetabulum within a Black African population in Kwa-Zulu Natal, South Africa. A total of 100 dry hip bones $(\mathrm{R}=44 ; \mathrm{L}=56)$ from the University of KwaZulu-Natal (Westville and NRMSOM campuses) were examined for this study. The hip bones, with documented sex, were all from the Black African population. A sliding digital caliper was used to measure the acetabular diameter, depth and acetabular notch width. The morphology of the acetabular margin was document in accordance with Govsa et al. (2005). Statistical analysis was conducted using SPSS version 24 software. A p-value of less than 0.05 was considered statistically significant. The means and standard deviations of the morphometric measurements for the entire population were as follows: (a) acetabular diameter of $54.84 \pm 4.18 \mathrm{~mm}$, (b) acetabular depth of $31.30 \pm 3.18 \mathrm{~mm}$ and (c) acetabular notch width of $21.72 \pm 2.98 \mathrm{~mm}$. The observed shapes of the acetabular margin that were angular (41\%), curved (22\%), irregular (23\%) and straight (14\%). Knowledge of the anatomy of the acetabulum is useful to surgeons, prosthetists, anthropologists and forensic anthropology experts. The morphometry and morphology of the Black African population group of KwaZulu-Natal presented with differences when compared to other population groups studied in literature.
\end{abstract}

KEY WORDS: Acetabulum; Morphometry; Morphology; Acetabular margin; Hip dysplasia.

\section{INTRODUCTION}

South Africa has a high incidence of unclaimed bodies that are used for educational and research purposes (Gangata et al., 2010). The use of unclaimed bodies raises ethical issues; therefore, it is necessary to develop ways of identifying unclaimed human remains. The acetabulum may be helpful to forensic anthropology experts during the identification process due to the differences it exhibits in sex and race (Dhindsa, 2013).

The acetabulum is the large cup-shaped cavity on the lateral surface of the hip bone, which articulates with the head of the femur to form the hip joint, which is responsible for the stability and movement of the entire lower limb (Moore et al., 2014). Since, the acetabulum is located in the central portion of the hip bone, it is consequently well preserved after death (Singh, 2014). The location and sexual dimorphism of the acetabulum makes it a useful structure for forensic experts to identify the sex of unknown human remains (Jeremic et al., 2011).

Marieb \& Hoehn (2013) stated that in general, female acetabula are smaller and farther apart in comparison to male acetabula. Rajasekhar et al. (2017) found male acetabula to be significantly larger in diameter than female acetabula. Furthermore, the acetabular depth was also found to be significantly larger in males than in females (Yugesh \& Kumar, 2016). Literature reports have concluded that the acetabulum is an accurate sex determinant of the hip bone (Rajangam et al., 1991; Murphy, 2000).

The morphology of the acetabular margin is clinically important in the diagnosis and treatment of injuries and diseases of the hip joint (Parmar et al., 2013). The shape of the acetabular margin is classified as irregular, curved, 
straight or angular (Govsa et al., 2005; Aksu et al., 2006; Maruyama et al., 2013; Vyas et al., 2013; Devi \& Philip, 2014; Ukoha et al., 2014). In the study conducted by Parmar et al. within the Indian population, the shape of the acetabular margin was observed to be either curved, straight or irregular only. They attributed the difference in morphology of the acetabular margin to ethnic origins.

Fractures and disease of the hip joint may result in severe pain of the joint and the lower limb (Hawker et al., 2008). Two types of hip disease, acetabular dysplasia and pincer femoro-acetabular impingement, are associated with morphological abnormalities of the acetabulum, including acetabular diameter, depth and orientation (Zeng et al., 2012). Therefore, in order to diagnose diseases of the hip and to perform appropriate surgical treatment, a knowledge of the anatomy of the acetabulum is necessary.

There have not been many studies conducted on the acetabulum within African populations and no studies on the acetabula of Black African populations within KwaZuluNatal. Therefore, this study aimed to document the morphometry and morphology of the acetabulum within the Black African population in KwaZulu-Natal, thus improving data on the acetabula of the Black African population. This data may aid surgeons during acetabular placements and designing better implants.

\section{MATERIAL AND METHOD}

The study was conducted on 100 dry hip bones $(\mathrm{L}=56$; $\mathrm{R}=44$ ), of known sex, obtained from the Clinical Anatomy, University of KwaZulu-Natal (Westville and NRMSOM campuses). The bones were all from the Black African population. Ethical Clearance was obtained from the Biomedical Research Ethics Committee (BE 382/17). The morphology of the acetabular margin was also documented as either curved, straight, angular or irregular according to Govsa et al.

The following morphometric parameters were measured three times using a sliding digital caliper to minimize intra-observer error and maximize reliability and validity of the study:

(a) acetabular diameter - vertical diameter of the acetabulum measured along the axis from the margin at the ischium to the anterior superior iliac spine (Fig. 1).

(b) acetabular depth - a thin metallic strip was placed across the diameter of the acetabulum and the perpendicular distance from the metallic strip to the deepest point of the acetabulum was measured (Fig. 2).

(c) acetabular notch width - widest distance of the notch determined by a line drawn perpendicular to the height of the notch (Fig. 3).

Statistical analysis was performed using SPSS version 24. The statistical tests conducted on the morphometric parameters were Descriptive Statistics and the IndependentSamples T Test. A correlation between the acetabular diameter and depth was investigated using the Pearson Chi squared test. A p-value of less than 0.05 was deemed statistically significant.

\section{RESULTS}

(i) Prevalence/Incidence. The acetabulum was present in $100 \%$ of the specimens as a large cup-shaped socket located on the lateral surface of the hip bone. Off the 100 specimens, 51 of the acetabula belonged to males (27 on the left side and 24 on the right side), while female acetabula amounted to 49 ( 29 on the left side and 20 on the right side).

\section{(ii) Morphometry}

a) Acetabular diameter. The mean and standard deviation of the acetabular diameter for the overall population was $54.84 \pm 4.18 \mathrm{~mm}$ (Table I). The mean and standard deviation of male and female acetabular diameter were $57.48 \pm 3.22$ $\mathrm{mm}$ and $52.09 \pm 3.16 \mathrm{~mm}$, respectively, with a statistically significant $\mathrm{p}$-value $<0.001$ (Table II).

b) Acetabular depth. The acetabular depth of the overall population had a mean and standard deviation of $31.30 \pm$ $3.18 \mathrm{~mm}$ (Table I). The results of males and females were $32.08 \pm 3.18 \mathrm{~mm}$ and $30.50 \pm 2.99 \mathrm{~mm}$, respectively, with a significant p-value of 0.012 (Table II). The relationship between the acetabular diameter and acetabular depth was investigated and a significant correlation of 0.01 was recorded.

c) Acetabular notch width. The mean acetabular notch width of the overall population was $21.72 \mathrm{~mm}$ with a standard deviation of $2.98 \mathrm{~mm}$ (Table I). The acetabular notch width of males and females were $22.32 \pm 3.37 \mathrm{~mm}$ and 21.09 $\pm 2.40 \mathrm{~mm}$, respectively, with a p-value of 0.039 (Table II).

(iii) Morphology. The shapes observed were $41 \%$ angular, $22 \%$ curved, $23 \%$ irregular and $14 \%$ straight (Fig. 4) (Tables III and IV). 


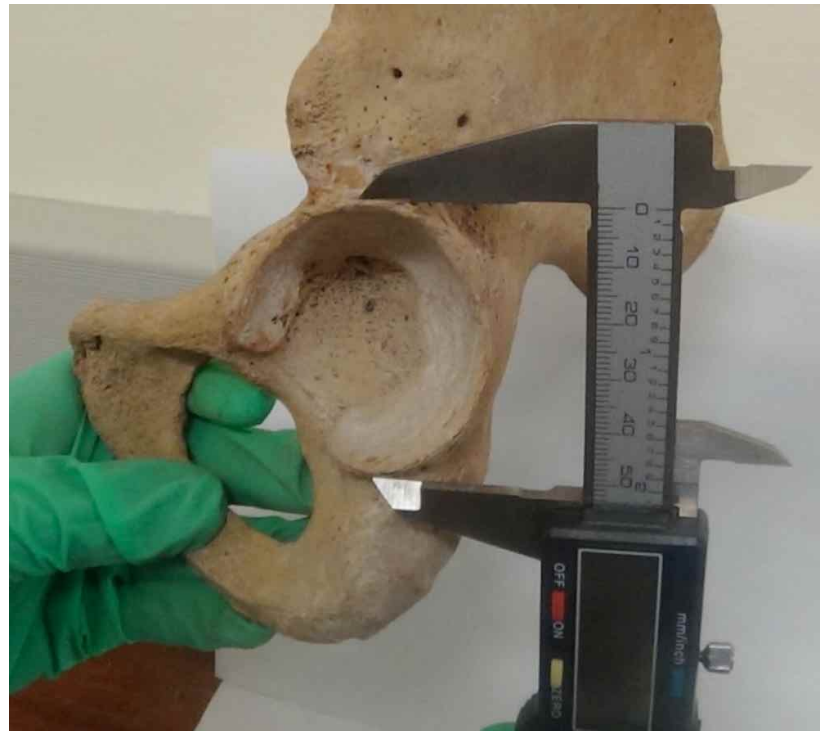

Fig. 1. Acetabular diameter.

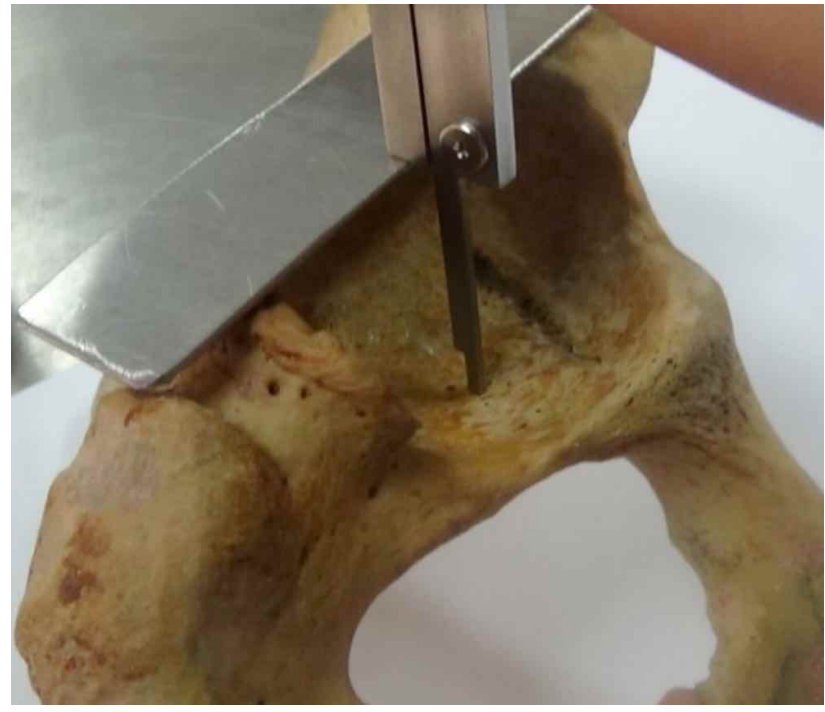

Fig. 2. Acetabular depth.

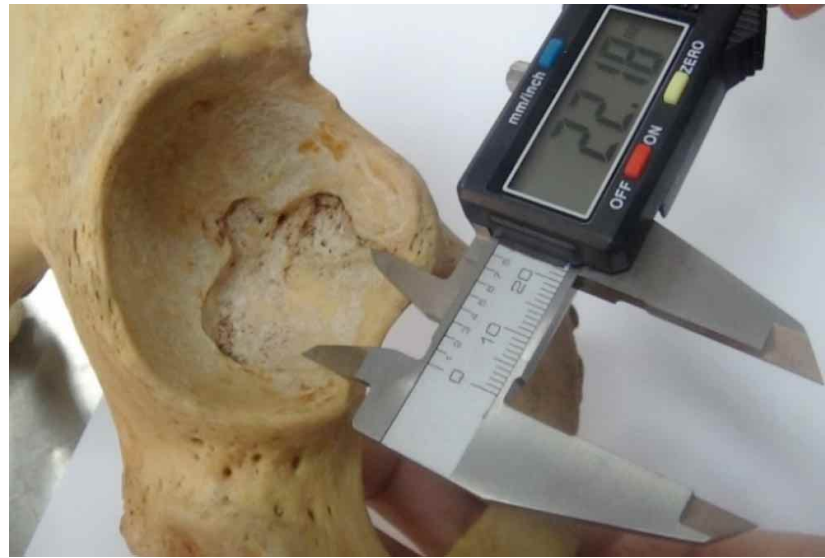

Fig. 3. Acetabular notch width.
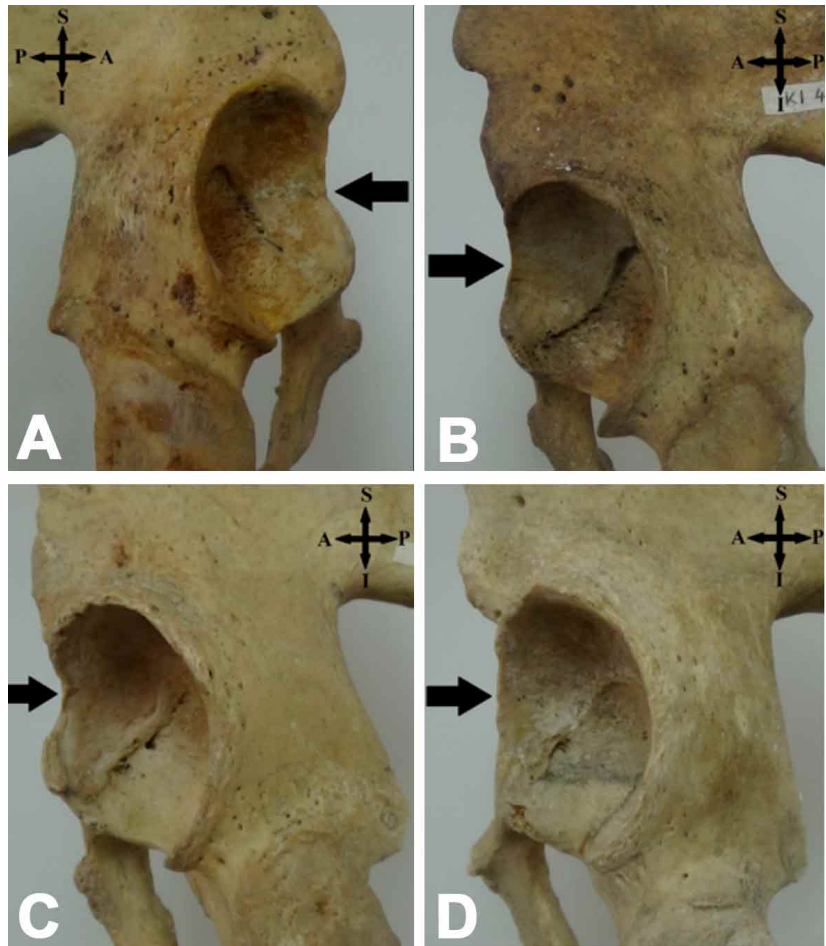

Fig. 4. Morphology of the acetabulum. Key: A: Angular shaped acetabular margin; B: Curved shaped acetabular margin; C: Irregular shaped acetabular margin; D: Straight shaped acetabular margin

Table I. Morphometric measurements of total population group (in mm).

\begin{tabular}{lcccc}
\hline Morphometric Parameter & Sample Size & Minimum & Maximum & Mean \pm Standard deviation \\
\hline Acetabular diameter & 100 & 45.63 & 63.10 & $54.84 \pm 4.18$ \\
Acetabular depth & 100 & 24.06 & 41.79 & $31.30 \pm 3.18$ \\
Acetabular notch width & 100 & 13.05 & 29.71 & $21.72 \pm 2.98$ \\
\hline
\end{tabular}

Table II. Morphometric measurements of males and females for left and right side (in mm).

\begin{tabular}{lccccc}
\hline \multirow{2}{*}{ Parameters } & \multicolumn{2}{c}{ Male } & \multicolumn{2}{c}{ Female } & \multirow{2}{*}{ p-value for sex } \\
\cline { 2 - 5 } & Left & Right & Left & Right & \\
\hline Acetabular diameter & $57.62 \pm 3.14$ & $57.31 \pm 3.37$ & $51.79 \pm 2.89$ & $52.52 \pm 3.55$ & $<0.001^{*}$ \\
Acetabular depth & $32.69 \pm 3.42$ & $31.39 \pm 2.80$ & $30.12 \pm 2.69$ & $31.04 \pm 3.39$ & $0.012^{*}$ \\
Acetabular notch width & $22.73 \pm 3.33$ & $21.85 \pm 3.42$ & $21.40 \pm 2.58$ & $20.65 \pm 2.08$ & $0.039^{*}$ \\
\hline
\end{tabular}

*Statistically significant. 
Table III. Morphology of the acetabular margin.

\begin{tabular}{cccccc}
\hline Morphology & \multicolumn{2}{c}{ Male } & \multicolumn{2}{c}{ Female } & Total \\
& Left & Right & Left & Right & \\
\hline Angular & $12(12 \%)$ & $9(9 \%)$ & $12(12 \%)$ & $8(8 \%)$ & $41(41 \%)$ \\
Curved & $5(5 \%)$ & $7(7 \%)$ & $6(6 \%)$ & $4(4 \%)$ & $22(22 \%)$ \\
Irregular & $6(6 \%)$ & $6(6 \%)$ & $6(6 \%)$ & $5(5 \%)$ & $23(23 \%)$ \\
Straight & $4(4 \%)$ & $2(2 \%)$ & $5(5 \%)$ & $3(3 \%)$ & $14(14 \%)$ \\
\hline
\end{tabular}

Table IV. Morphology of acetabular margin in different population groups.

\begin{tabular}{lcccccc}
\hline Author & Year & $\begin{array}{c}\text { Sample } \\
\text { Size }\end{array}$ & Curved & Straight & Angular & Irregular \\
\hline Govsa et al. & 2005 & 226 & $98(43.36 \%)$ & $27(11.94 \%)$ & $64(28.33 \%)$ & $37(16.47 \%)$ \\
Aksu et al. & 2006 & 154 & $71(46.1 \%)$ & $36(23.3 \%)$ & $26(16.8 \%)$ & $21(13.6 \%)$ \\
Maruyama et al. & 2013 & 200 & $121(60.5 \%)$ & $9(4.5 \%)$ & $51(25.5 \%)$ & $19(9.5 \%)$ \\
Vyas et al. & 2013 & 152 & $57(37.5 \%)$ & $48(31.6 \%)$ & $19(12.5 \%)$ & $28(18.4 \%)$ \\
Parmar et al. & 2013 & 100 & $61(61 \%)$ & $20(20 \%)$ & $0(0 \%)$ & $19(19 \%)$ \\
Devi \& Philip & 2014 & 100 & $60(60 \%)$ & $4(4 \%)$ & $27(27 \%)$ & $9(9 \%)$ \\
Ukoha et al. & 2014 & 100 & $35(35 \%)$ & $23(23 \%)$ & $33(33 \%)$ & $9(9 \%)$ \\
Present study & 2017 & 100 & $22(22 \%)$ & $14(14 \%)$ & $41(41 \%)$ & $23(23 \%)$ \\
\hline
\end{tabular}

\section{DISCUSSION}

The present study found male acetabula to be larger in diameter than female acetabula, with a p-value of $<0.001$, deeming this result highly significant. This correlated with previous studies, which reported that males had a larger acetabular diameter than females (Chauhan et al., 2002; Zeng et al.; Yugesh \& Kumar; Rajasekhar et al.). This finding was statistically significant in the studies conducted by Chauhan et al., Zeng et al., Yugesh \& Kumar and Rajasekhar et al. However, the finding was insignificant in the study conducted by Krebs et al. (2009) on the acetabula of AfricanAmerican and Caucasian people in America (Table V).

The overall mean acetabular diameter in the present study was most similar to the results of Ukoha et al., who documented the acetabular diameter to be $55.8 \pm 3.7 \mathrm{~mm}$ on the right side and $54.6 \pm 3.0 \mathrm{~mm}$ on the left side in the Nigerian population.
In the present study, the mean acetabular depth was significantly greater in males than in females ( $\mathrm{p}$-value $=$ 0.012). This finding corroborated the recent study of who studied the acetabulum of the South Indian population. The acetabular depth of the Black African population of KwaZulu-Natal was greater than population groups documented by other authors (Table VI). The results in the present study were most similar to the Nigerian population where the depth of the acetabulum was documented to be $29.7 \pm 3.1 \mathrm{~mm}$ on the right side and $30.2 \pm 3.1 \mathrm{~mm}$ on the left side (Ukoha et al.).

The correlation test used to investigate the relationship between acetabular diameter and depth was necessary due to the clinical significance of these two parameters in diagnosing disease and in surgical treatment (Baharuddin et al., 2011). The findings from this study reflect that in the Black African

Table V. Mean diameter of the acetabulum in different population groups (in $\mathrm{mm}$ )

\begin{tabular}{|c|c|c|c|c|c|}
\hline \multirow[t]{2}{*}{ Author } & \multirow[t]{2}{*}{ Year } & \multirow[t]{2}{*}{ Population } & \multirow[t]{2}{*}{ Sample size } & \multicolumn{2}{|c|}{ Diameter of acetabulum } \\
\hline & & & & Male & Female \\
\hline \multirow[t]{2}{*}{ Chauhan et al. } & 2002 & North Indian & 48 & $47.10 \pm 2.90(\mathrm{R})$ & $44.38 \pm 3.01(\mathrm{R})$ \\
\hline & & & & $47.48 \pm 3.05(\mathrm{~L})$ & $46.0 \pm 2.28(\mathrm{~L})$ \\
\hline Krebs et al. & 2009 & American & 100 & $53.7 \pm 3.47$ & $47.0 \pm 2.47$ \\
\hline \multirow[t]{2}{*}{ Zeng et al. } & 2012 & Chinese & 200 & $55.2 \pm 3.11(\mathrm{R})$ & $51.4 \pm 2.38(\mathrm{R})$ \\
\hline & & & & $56.0 \pm 3.33(\mathrm{~L})$ & $51.4 \pm 2.07(\mathrm{~L})$ \\
\hline Yugesh \& Kumar & 2016 & South Indian & 60 & $48.66 \pm 0.33$ & $46.18 \pm 0.24$ \\
\hline Rajasekhar et al. & 2017 & South Indian & 206 & $48.1 \pm 3.1$ & $45.2 \pm 3.5$ \\
\hline \multirow[t]{2}{*}{ Present study } & 2017 & South African & 100 & $57.31 \pm 3.37(\mathrm{R})$ & $52.52 \pm 3.55(\mathrm{R})$ \\
\hline & & & & $57.62 \pm 3.14(\mathrm{~L})$ & $51.79 \pm 2.89(\mathrm{~L})$ \\
\hline
\end{tabular}


population of KZN, individuals with a larger acetabular diameter may also have a deeper acetabulum.

The acetabular notch width in the present study was significantly larger in males than in females (p-value of 0.039). This contradicts the study of Yugesh \& Kumar who reported an insignificant larger acetabular notch width in females than in males within the South Indian population (Table VII). The acetabular notch width of the entire population in the present study was smaller in comparison to the notch width reported by Yugesh \& Kumar and Gillard et al. (2013) on South Indian and German populations, respectively.

\section{CONCLUSION}

A better understanding of the anatomy of the acetabulum may assist surgeons and prosthetists in determining the difference between a normal acetabulum and a diseased or damaged one for the Black African population of KwaZulu-Natal. The acetabula investigated in the present study exhibited significant morphometric differences between males and females, making it a good sex indicator for the Black African population of KwaZuluNatal. These differences in acetabular morphology may have be attributed to ethnic origins (Parmar et al.). The acetabular morphology in the Black African population group of KwaZulu-Natal presented a marked difference as compared to other population groups. Therefore, the present study may contribute to reducing the incidence of unclaimed bodies in South Africa due to the usefulness of the acetabulum in sex and race identification.

The findings in the present study suggest that populations in Sub-Saharan Africa present with a similar morphology. Further research needs to be conducted on the acetabula of different African populations due to the morphometric and morphological similarities between the Black African population group of KwaZulu-Natal and the Nigerian population studied by Ukoha et al.

Table VI. Mean depth of the acetabulum in different population groups (in mm)

\begin{tabular}{|c|c|c|c|c|c|}
\hline \multirow[t]{2}{*}{ Author } & \multirow[t]{2}{*}{ Year } & \multirow[t]{2}{*}{ Population } & \multirow[t]{2}{*}{ Sample size } & \multicolumn{2}{|c|}{ Depth of acetabulum (mm) } \\
\hline & & & & Male & Female \\
\hline \multirow[t]{2}{*}{ Chauhan et al. } & 2002 & North Indian & 48 & $27.49 \pm 2.70(\mathrm{R})$ & $24.68 \pm 1.20(\mathrm{R})$ \\
\hline & & & & $28.18 \pm 2.58(\mathrm{~L})$ & $25.70 \pm 2.11(\mathrm{~L})$ \\
\hline \multirow[t]{2}{*}{ Baharuddin et al. } & 2011 & Malaysian & 120 & $16.05 \pm 1.75(\mathrm{R})$ & $14.63 \pm 1.63(\mathrm{R})$ \\
\hline & & & & $16.29 \pm 1.24(\mathrm{~L})$ & $14.99 \pm 1.62(\mathrm{~L})$ \\
\hline \multirow[t]{2}{*}{ Zeng et al. } & 2012 & Chinese & 200 & $19.3 \pm 2.48(\mathrm{R})$ & $17.3 \pm 1.68(\mathrm{R})$ \\
\hline & & & & $19.4 \pm 2.21(\mathrm{~L})$ & $17.4 \pm 1.58(\mathrm{~L})$ \\
\hline Arsi_et al. & 2013 & Serbian & 58 & $26.47 \pm 7.73$ & $22.01 \pm 4.78$ \\
\hline Yugesh \& Kumar & 2016 & South Indian & 60 & $30.00 \pm 0.22$ & $21.45 \pm 0.22$ \\
\hline \multirow[t]{2}{*}{ Present study } & 2017 & South African & 100 & $31.39 \pm 2.80(\mathrm{R})$ & $31.04 \pm 3.39(\mathrm{R})$ \\
\hline & & & & $32.69 \pm 3.42(\mathrm{~L})$ & $30.12 \pm 2.69(\mathrm{~L})$ \\
\hline
\end{tabular}

$(\mathrm{R})=$ Right side and $(\mathrm{L})=$ Left side .

Table VII. Mean width of the acetabular notch in different population groups.

\begin{tabular}{lccccc}
\hline \multicolumn{1}{c}{ Author } & Year & Population & Sample size & \multicolumn{2}{c}{$\begin{array}{c}\text { Width of acetabular notch }(\mathrm{mm}) \\
\text { Male }\end{array}$} \\
& & & & $30.47 \pm 0.70$ & $31.77 \pm 0.39$ \\
Yugesh \& Kumar & 2016 & South Indian & 60 & $21.85 \pm 3.42(\mathrm{R})$ & $20.65 \pm 2.08(\mathrm{R})$ \\
Present study & 2017 & South African & 100 & $22.73 \pm 3.33(\mathrm{~L})$ & $21.40 \pm 2.58(\mathrm{~L})$ \\
& & & & &
\end{tabular}

$(\mathrm{R})=$ Right side and $(\mathrm{L})=$ Left side

INDURJEETH, K.; ISHWARKUMAR, S.; DE GAMA, B. Z.; NDLAZI, Z. \& PILLAY, P. Morfometría y morfología del acetábulo dentro de la población africana negra de Sudáfrica. Int J. Morphol., 37(3):971-976, 2019.

RESUMEN: El acetábulo es una cavidad grande, en for- ma de copa, ubicada en la superficie lateral del hueso coxal, que se articula con la cabeza del fémur para formar la articulación coxofemoral. La morfometría y morfología del acetábulo son importantes en el diagnóstico y tratamiento de las lesiones y enfermedades de las articulaciones de la cadera. Existen diferencias específicas de la población con respecto al acetábulo, por lo tanto, 
este estudio tuvo como objetivo documentar la morfometría y la morfología del acetábulo en una población Africana negra, perteneciente a Kwa-Zulu Natal, Sudáfrica. Para este estudio se examinaron un total de 100 huesos coxales secos $($ Right $=44 ;$ Left $=56)$ de la Universidad de KwaZulu-Natal (campus de Westville y NRMSOM). Los huesos coxales, con sexo documentado, eran todos de población africana negra. Se utilizó un calibrador digital deslizante para medir el diámetro acetabular, la profundidad y el ancho de la incisura acetabular. La morfología del margen acetabular anterior se documentó de acuerdo con Govsa et al. (2005). El análisis estadístico se realizó utilizando el software SPSS versión 24. Un valor de p inferior a 0,05 se consideró estadísticamente significativo. Las medias y desviaciones estándar de las medidas morfométricas para toda la población fueron las siguientes: (a) diámetro acetabular de $54,84 \pm 4.18 \mathrm{~mm}$, (b) profundidad acetabular de 31,30 $\pm 3,18 \mathrm{~mm}$ y (c) ancho de la incisura acetabular de 21,72 $\pm 2,98 \mathrm{~mm}$. Las formas observadas del margen acetabular fueron angulares $(41 \%)$, curvas $(22 \%)$, irregulares $(23 \%)$ y rectas $(14 \%)$. El conocimiento de la anatomía del acetábulo es útil para cirujanos, antropólogos y expertos en antropología forense. La morfometría y morfología del grupo poblacional de África negra de KwaZulu-Natal presentaron diferencias cuando se compararon con otros grupos poblacionales estudiados en la literatura.

PALABRAS CLAVE: Acetábulo; Morfometría; Morfología; Margen acetabular; Displasia de cadera.

\section{REFERENCES}

Baharuddin, M. Y.; Zulkifly, A. H.; Kadir, M. R. A.; Saat, A.; Aziz, A. A. \& Lee, M. H. Morphometric study of the acetabular in Malay population normal hips and its clinical applications. J. Med. Sci., 11(5): 213-9, 2011.

Chauhan, R.; Paul, S. \& Dhaon, B. K. Anatomical parameters of North Indian hip joints - Cadaveric study. J. Anat. Soc. India, 51(1):39-42, 2002.

Devi, T. B. \& Philip, X. C. Acetabulum - Morphological and morphometrical study. Res. J. Pharm. Biol. Chem. Sci., 5(6):793-9, 2014.

Gangata, H.; Ntaba, P.; Akol, P. \& Louw, G. The reliance on unclaimed cadavers for anatomical teaching by medical schools in Africa. Anat. Sci. Educ., 3(4):174-83, 2010.

Gillard, F. C.; Dickinson, A. S.; Schneider, U.; Taylor, A. C. \& Browne, M. Multi-pelvis characterisation of articular cartilage geometry. Proc. Inst. Mech. Eng. H, 227(12):1255-64, 2013.

Govsa, F.; Ozer, M. A. \& Ozgur, Z. Morphologic features of the acetabulum. Arch. Orthop. Trauma Surg., 125(7):453-61, 2005.

Hawker, G. A.; Stewart, L.; French, M. R.; Cibere, J.; Jordan, J. M.; March, L.; Suarez-Almazor, M. \& Gooberman-Hill, R. Understanding the pain experience in hip and knee osteoarthritis--an OARSI/OMERACT initiative. Osteoarthritis Cartilage, 16(4):415-22, 2008.

Jeremic, D.; Jovanovic, B.; Zivanovic-Macuzic, I.; Dordevic, G.; Sazdanovic, M.; Dordevic, M.; Sazdanovic, P.; Vulovic, M. \& Tosevski, J. Sex dimorphism of postural parameters of the human acetabulum. Arch. Biol. Sci., 63(1):137-43, 2011.

Krebs, V.; Incavo, S. J. \& Shields, W. H. The anatomy of the acetabulum: what is normal? Clin. Orthop. Relat. Res., 467(4):868-75, 2009.

Marieb, E. N. \& Hoehn, K. Human Anatomy \& Physiology. $9^{\text {th }}$ ed. Boston, Pearson, 2013.
Maruyama, M.; Feinberg, J. R.; Capello, W. N. \& D'Antonio, J. A Morphology of the pelvis (acetabulum) and femur. In: Subramanium, V. \& Bhatnagar, M. Trabecular and Cortical Bone: Morphology, Biomechanics and Clinical Implications. Hauppauge, Nova Science Publishers, 2013. pp.163-89.

Moore, K. L.; Dalley, A. F. \& Agur, A. M. R. Clinically Orientated Anatomy. 7th ed. Philadelphia, Wolters Kluwer Health/Lippincott Williams \& Wilkins, 2014. pp.514-6.

Murphy, A. M. The acetabulum: sex assessment of prehistoric New Zealand Polynesian innominates. Forensic Sci. Int., 108(1):39-43, 2000.

Parmar, G.; Ruparelia, S.; Patel, S. V.; Patel, S. M. \& Jethva, N. Morphology and morphometry of acetabulum. Int. J. Biol. Med. Res., 4(1):2924-6, 2013.

Rajangam, S.; Janakiram, S. \& Thomas, I. M. Sexing of hip bones of Karnataka origin. J. Anat. Soc. India, 40(2):105-8, 1991.

Rajasekhar, S.; Vasudha, T. K. \& Aravindhan, K. Sex Determination by biometry of anterior features of human hip bones in South Indian population. J. Clin. Diagn. Res., 11(6):AC13-AC16, 2017.

Singh, G. K. Measurement of various parameters of greater sciatic notch of pelvis. Indian J. Appl. Res., 4(10):28-30, 2014.

Ukoha, U. U.; Umeasalugo, K. E.; Okafor, J. I.; Ndukwe, G. U.; Nzeakor, H. C. \& Ekwunife, D. O. Morphology and morphometry of dry adult acetabula in Nigeria. Rev. Argent. Anat. Clin., 6(3):150-5, 2014.

Vyas, K.; Shroff, B. \& Zanzrukiya, K. An osseous study of morphological aspect of acetabulum of hip bone. Int. J. Res. Med., 2(1):78-82, 2013.

Yugesh, K. \& Kumar, S. S. Morphometric analysis of acetabulum and its clinical correlation in south Indian population. Int. J. Appl. Res., 2(6):1011-4, 2016.

Zeng, Y.; Wang, Y.; Zhu, Z.; Tang, T.; Dai, K. \& Qiu, S. Differences in acetabular morphology related to side and sex in a Chinese population. J. Anat., 220(3):256-62, 2012.

\section{Corresponding author:}

Dr. P. Pillay

Department of Clinical Anatomy

School of Laboratory Medicine and Medical Sciences

College of Health Sciences

University of KwaZulu-Natal

Westville Campus

Private Bag X54001

Durban, 4000

SOUTH AFRICA

Email: soobramoneypa@ukzn.ac.za

Received: 26-09-2018

Accepted: 06-02-2019 